\title{
رهن المباني القائمة على أرض الغير في القانون المدني الجزائري
}

\section{مقدمة}

إذأ كان عقد الرهن الرسمي يهدف في

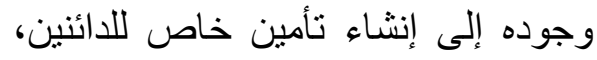

يضمن لهم استيفاء حقوقهم كاملة، فهذاء

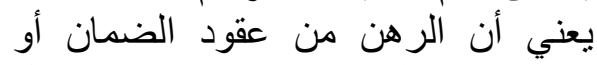

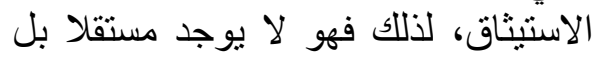

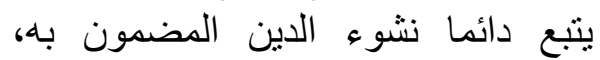

بحيث يكون هناك تقابل بين نشوء التئ الدين

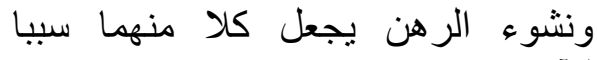

للآخر .

فإن من شرئ شروط انعقاد الرهن

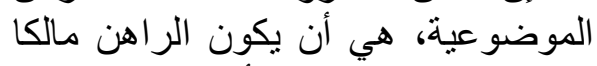

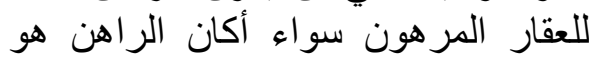

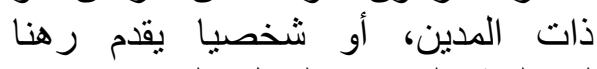
لمصلحة المدين "الكفيل العيني"، فعقد

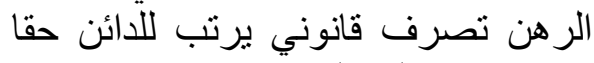

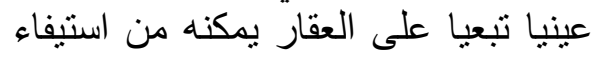

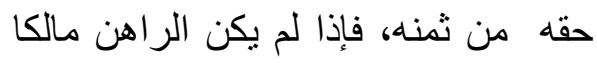

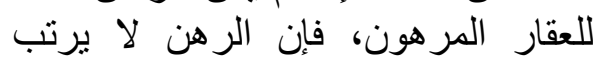

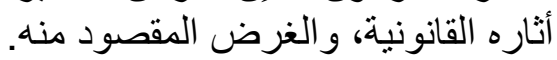

\section{Abstract}

The building's owner or establisher's owner which poll on the land of others can encumber it. So, the creditors mortgagee will found his right either of the price of ruins of the mortgaged property, or of the compensation paid by the owner of the land, if they owning the mortgaged property. or from the price to sell it at auction. 


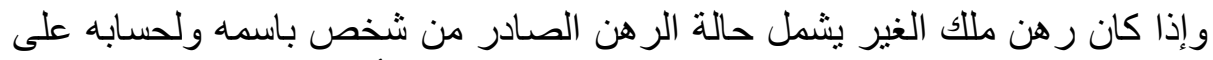

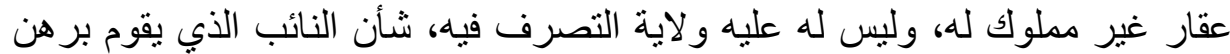
عقار الأصيل متجاوز أحدود النيابة ولئ.

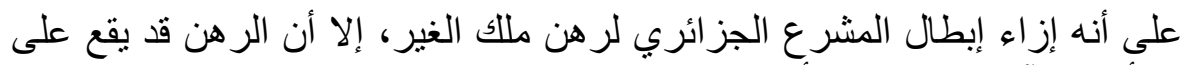

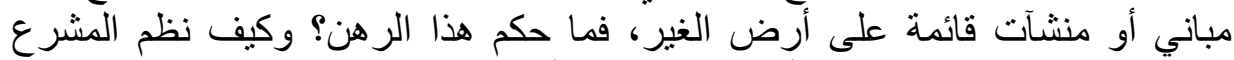

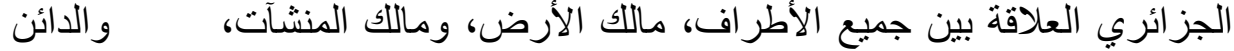

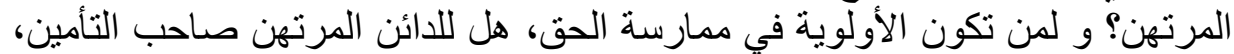

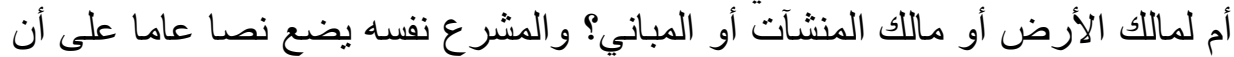

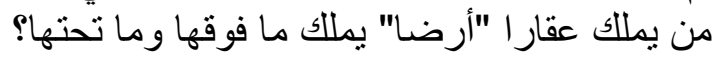
بناء على هذه التساؤ لات و الإشكالات القانونية، قسمت محاور الدر اسة إلى ثلاثة: المحور الأول: وسائل ضمان حقوق لالد الدائنين.

$$
\text { - }
$$

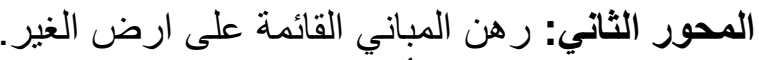

- - العلاقة بين ماللك الأرض وضئ والمدين الر الهن و الدائن المرتهن.

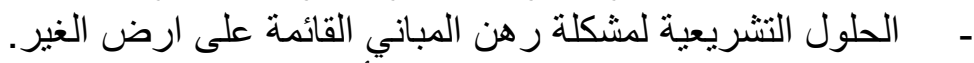

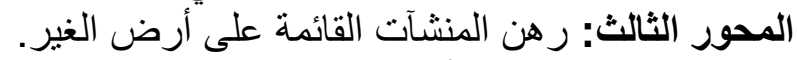

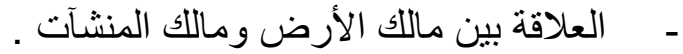
- - مالعلاقة بين ماللك المنشآت و والدائن المرتهن.

\section{المحور الأول}

\section{وسائل ضمان حقوق الدائنين}

الأخطار التي تهدد الثخص متنوعة وكثيرة، و التأمينات بمعناها الواسع بقصد بهان التها

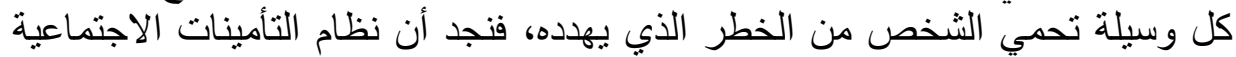

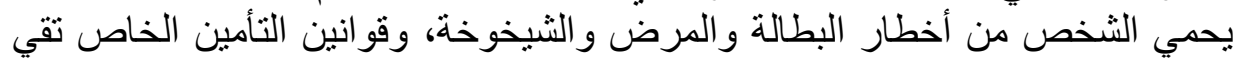
الثخص من الأخطار التي تهدد ماله أو جسمه النه

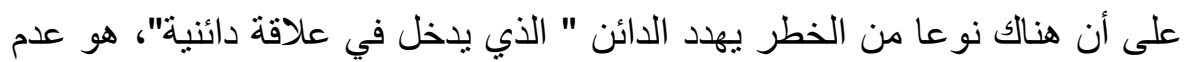

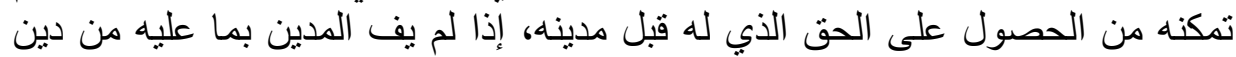

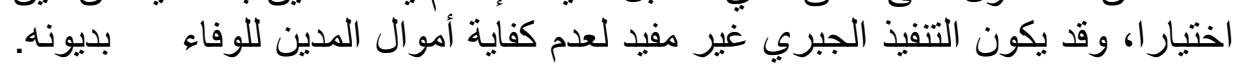

لذا فقد نص المشرع الجزائري على نو عين من الوسائل لتأمين حق الدائن اتجاه مدينه 


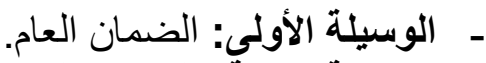

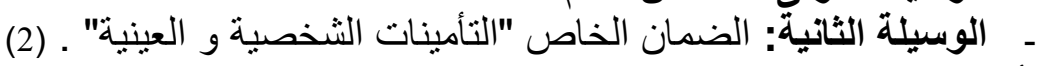
أولا: التعريف بالضمان العام و الضمان الخديره

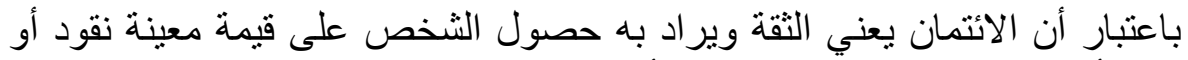

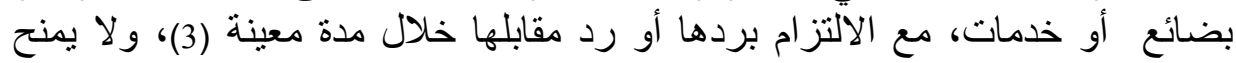

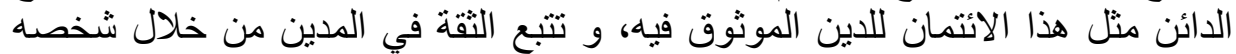

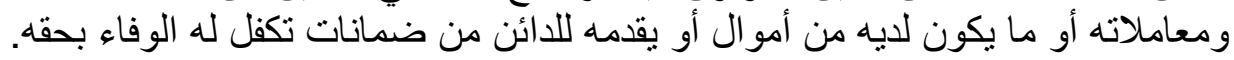

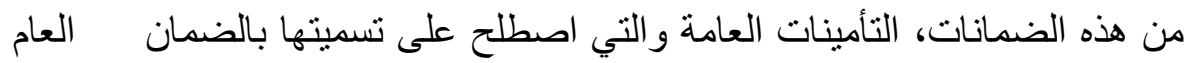

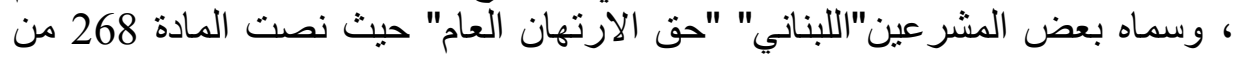
قانون الموجبات و العقود اللبناني:

"للائن حق ارتهان عام على مملوك المدين بمجمو عه، لا على أفر اد ممتلكاته ...."

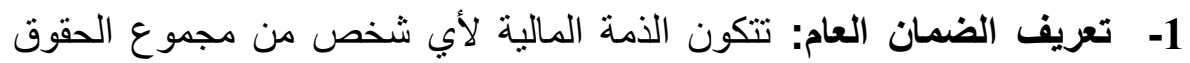

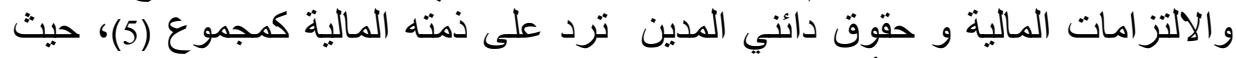

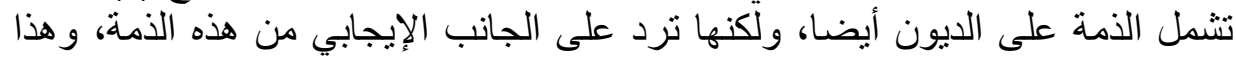

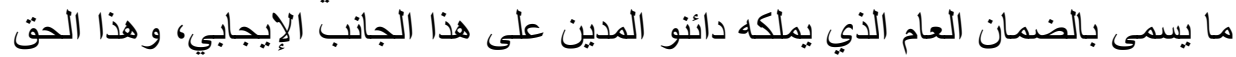

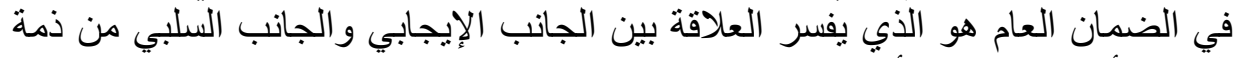

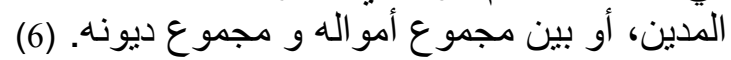

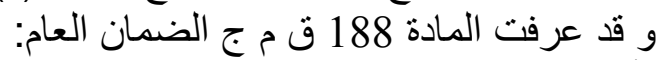

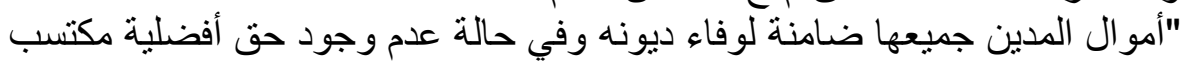

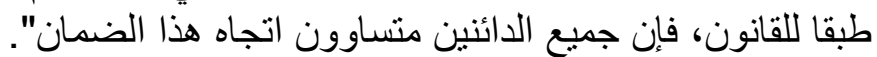

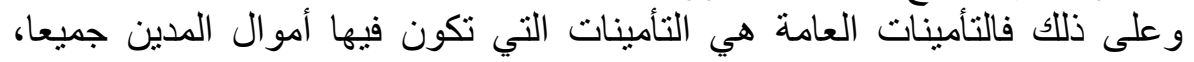

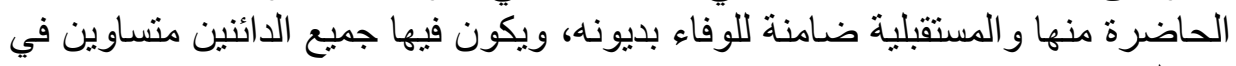

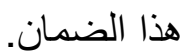

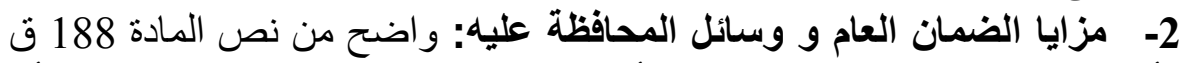

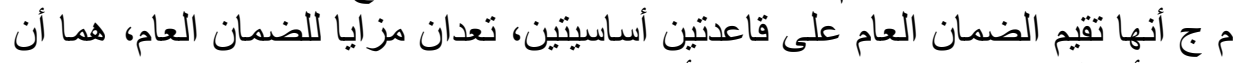

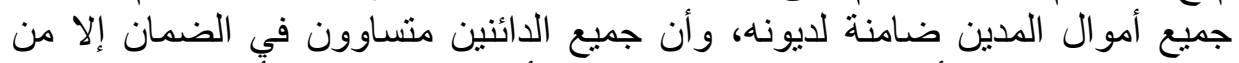

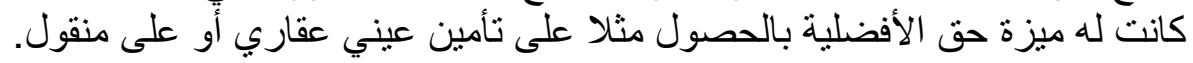

\section{أ. جميع أموال المدين ضامنة للوفاء بديونه:}

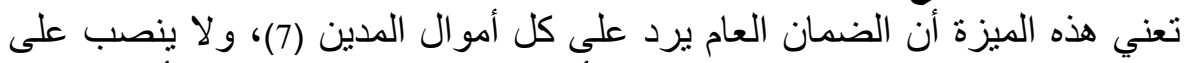

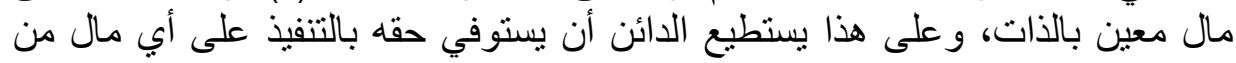


أموال المدين وقت نشوء الدين أو أية أموال أخرى يكسبها المدين بعد ذللك، وهذا

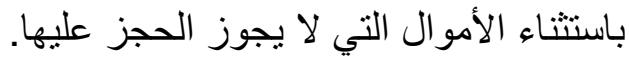

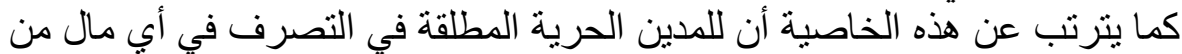

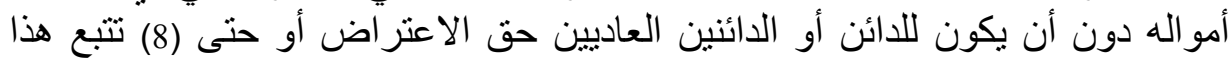

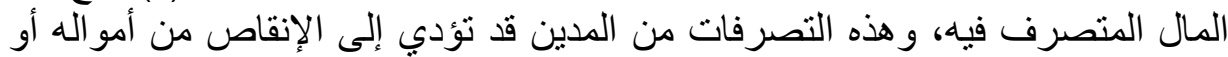

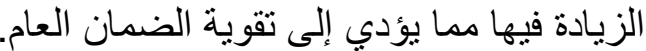

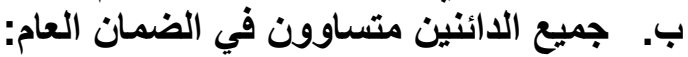

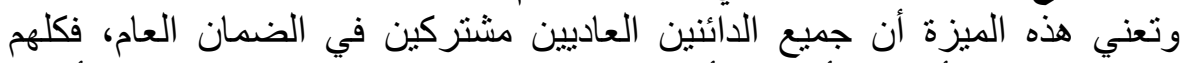

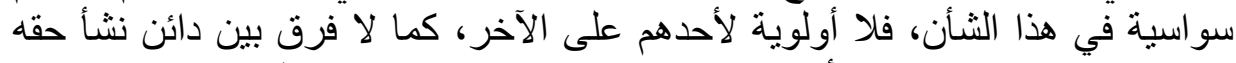

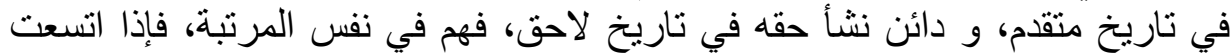

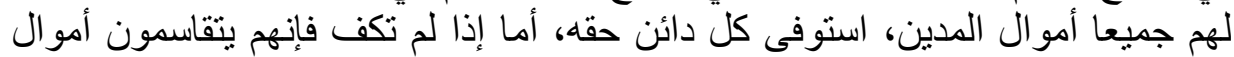

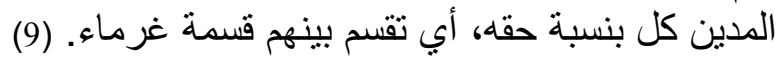

أما من حيث وسائل تدعيم الضمان العام و حمايته: فهي أيضا متعددة في القانون، بين الإجراءات التحفظية و الدعاوى التي يسلكها التها الدائن العادي.

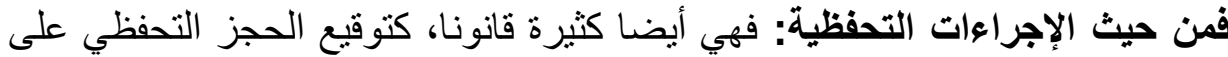

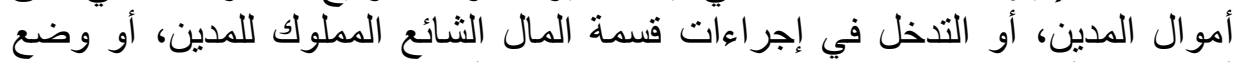

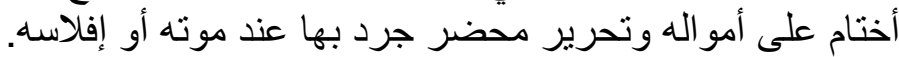

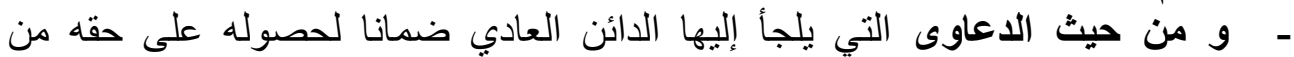
المدين، فهي كثيرة و أهمها: ه الدعوى غير المباثرة / م 189 / 190 ق م م ج: برفع الدائن دعوى على مدين المدين، إذا تقاعس المدين في المطالبة بحقه، وقد يؤدي ذلك إلى إلى الزيادئ في في

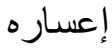

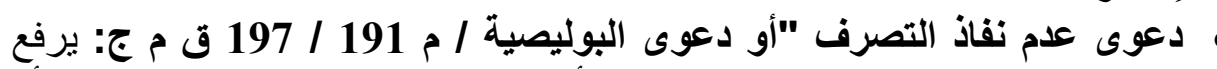

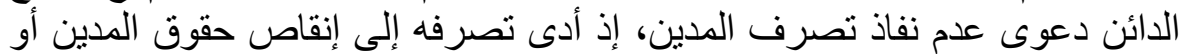

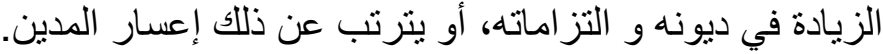

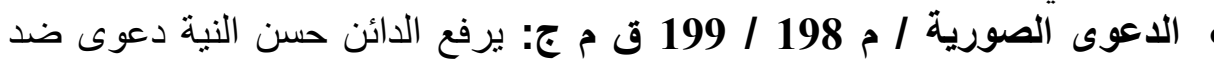
المدين لإثبات صورية تصرفه و من المن ثم التمسك بالعقد الحقيقي

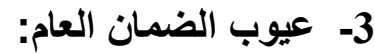

$$
\text { من أهم عيوب الضمان العام: }
$$

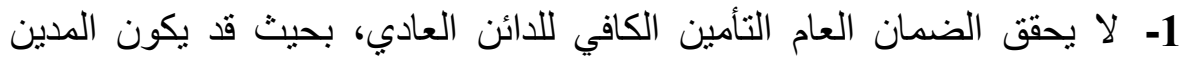

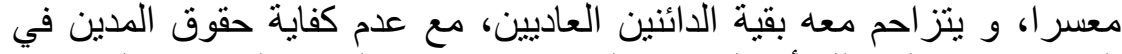
الوفاء، ضف إلى ذلك أن الضمان العام لا يمنع عن المدين الحق في التصن التصرف

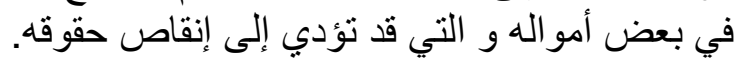




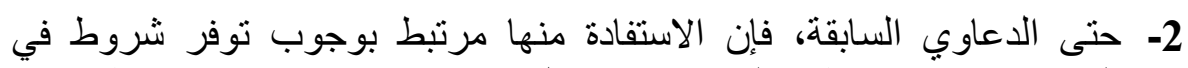

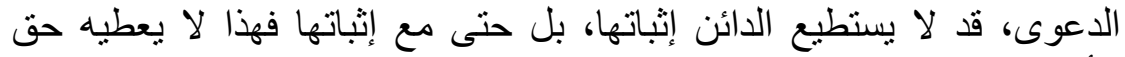

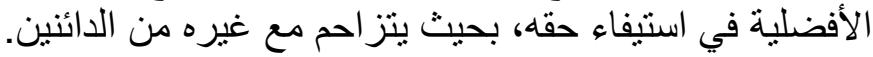

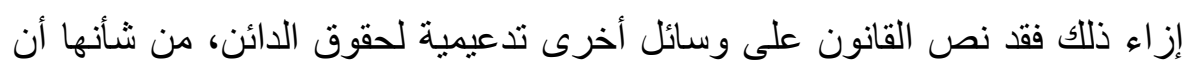

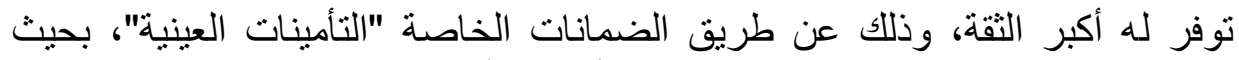

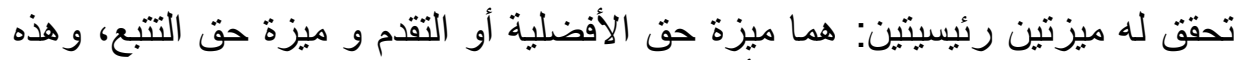

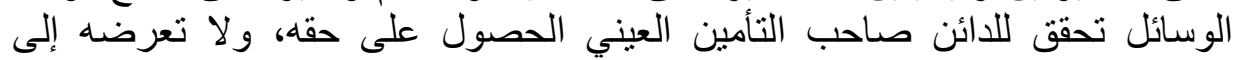
المخاطر التي يتعرض لهائل كل دائن عادي.

ثانيا: التعريف بالضمان الخاص و تقديره

\section{1- التعريف بالضمان الخاص ووسائلة:}

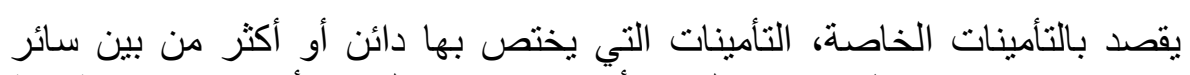

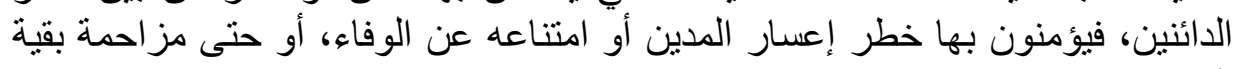

الدائنين.

و يتحقق التأمين الخاص في صورتين، تأمينات شخصية وتأمينات عينية.

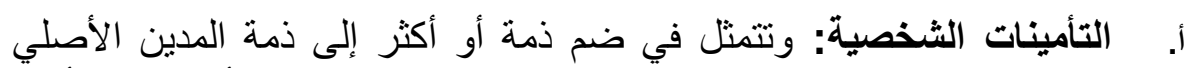

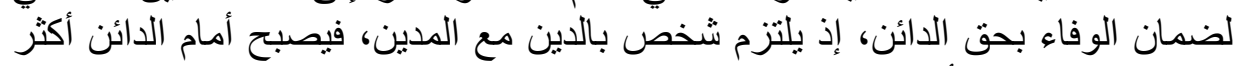

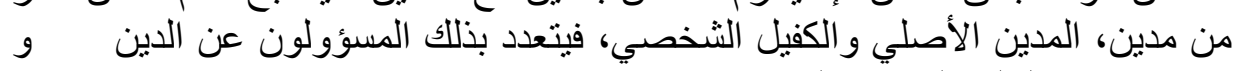
من نم يتعدد بالتالي الضمان الإن العام. (10)

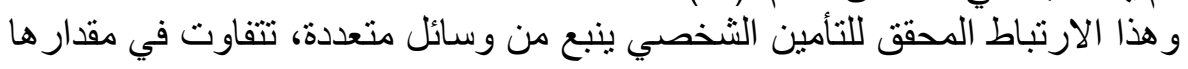

عليه: - فهناك الاشتر اط لمصلحة الغير و الذي يحقق للمنتفع تأمينا شخصيا عندما يكون دائنا سابقا للمشترط.

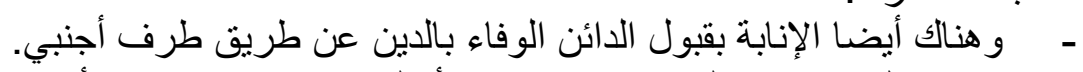

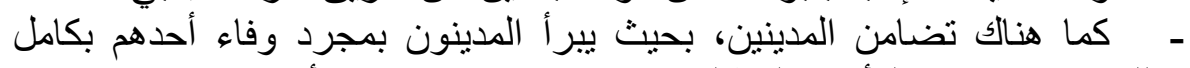
الدين للائن، كما يجوز للأخير المطالبة منهم جميعا إما مجتمعين أبنان أو منفردين.

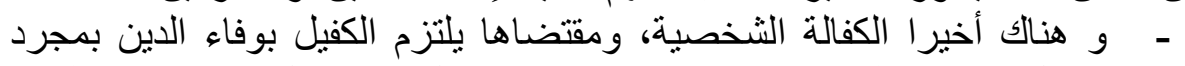

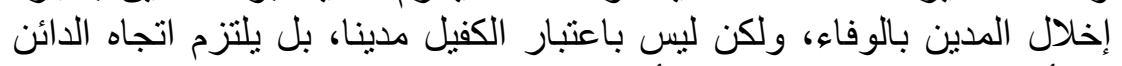

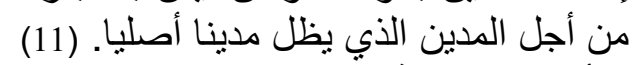

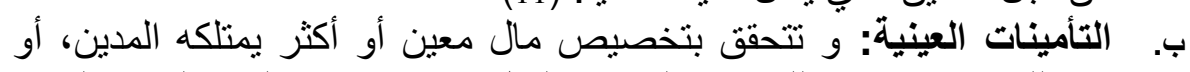

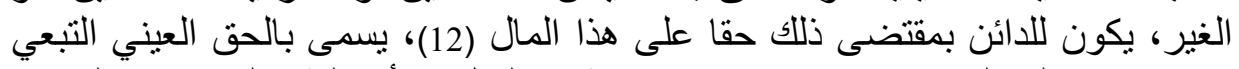

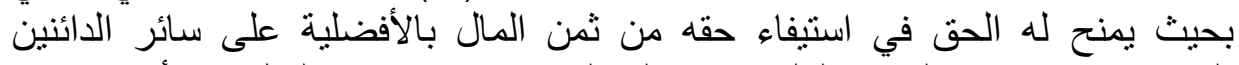

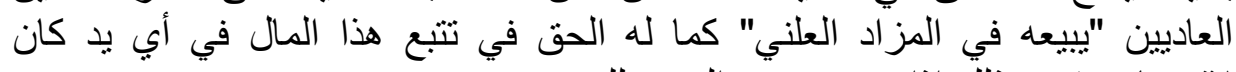
لاقتضاء حقه، وذلك إذا تصرف فئ فيه المدين للغير. (13) في لهن 


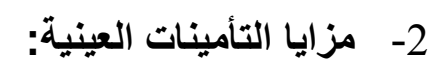

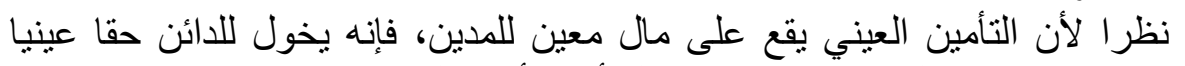

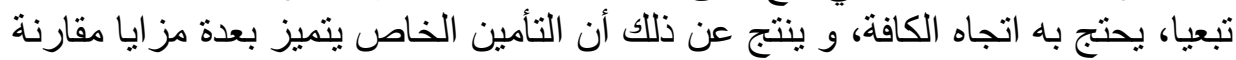

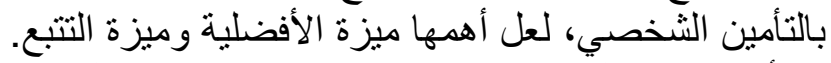

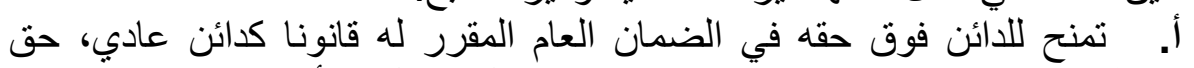

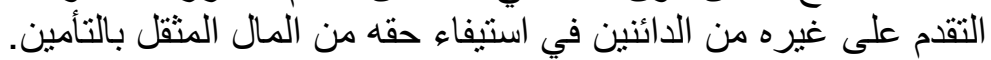

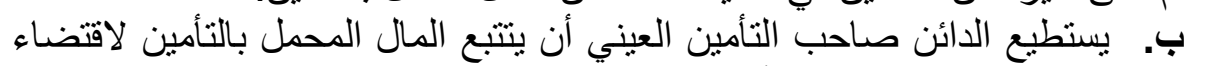

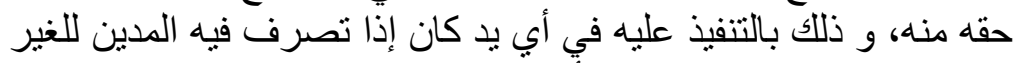

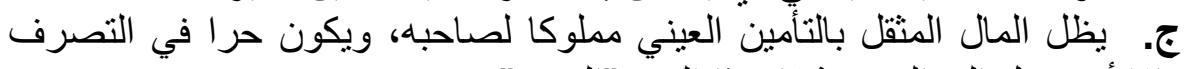
فيه، إلا أنه ينتقل إلى الغير مثقلا بهذا الحق "الكئل الديون".

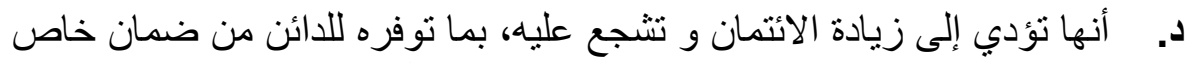

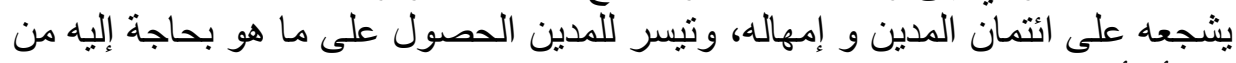

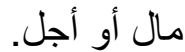

إزاء كل ذللك فضل بعض المشرعين تسمية التأمينات الخاصة بالحقوق العينية

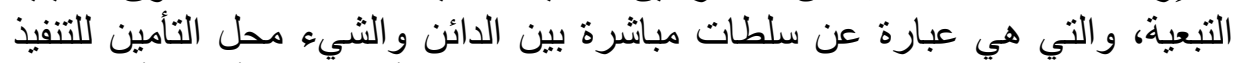

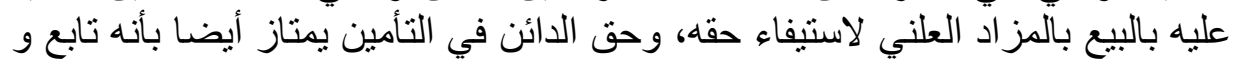

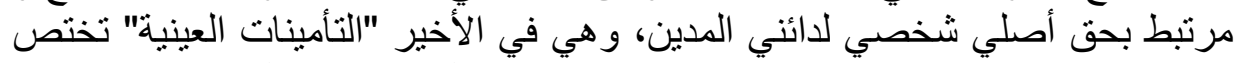
بعدم التجزئة في الضمان، فالثيء بكامله ضامن لكل الدين، الدين، وكل جزء من الدين

$$
\text { 3ضمون من الثنيء. }
$$

قد تتحقق أبضا للتأمينات بعض العينة العيوب وهي قليلة مقارنة بمز اياها، لعل أهمها:

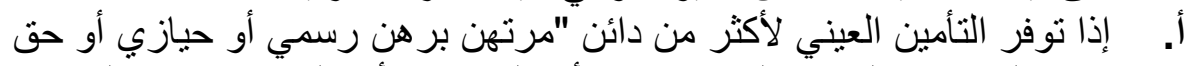

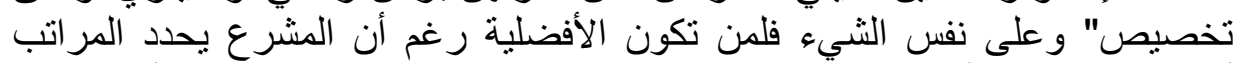

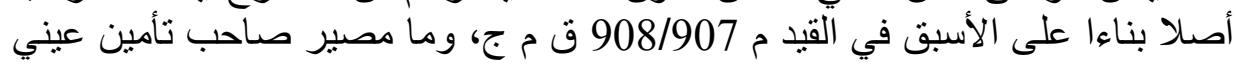

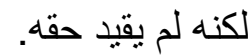

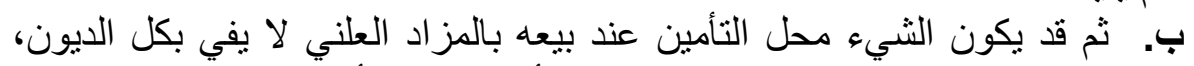

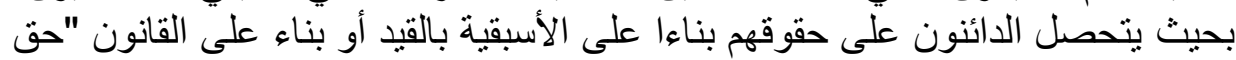

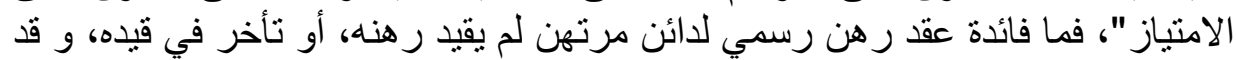

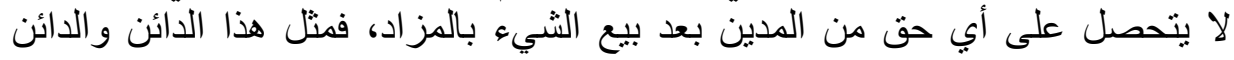

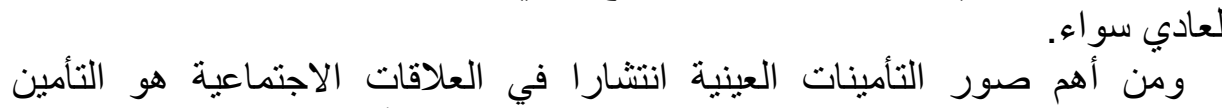

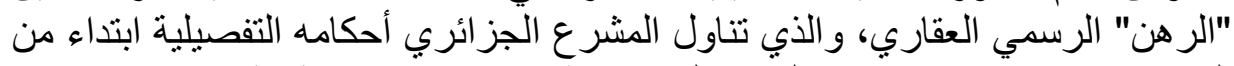

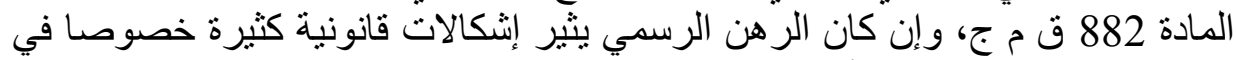

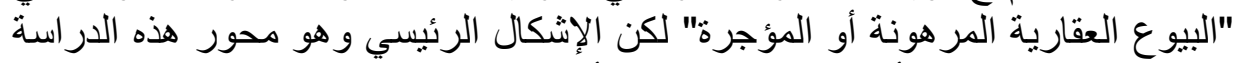

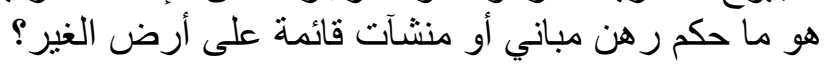


لا يمكن معرفة هذا الحكم إلا بإعطاء تعريفا للرهن الرسمي، ومن ثم تحديد مزاياه

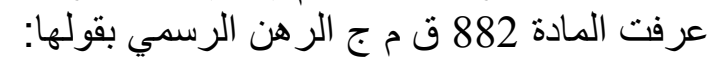

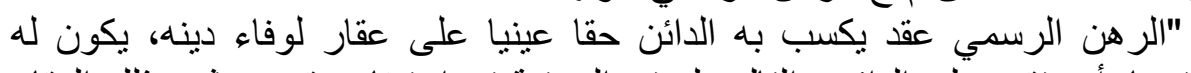

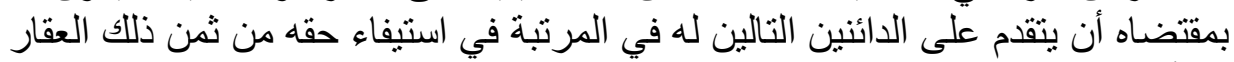

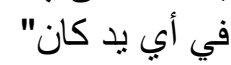

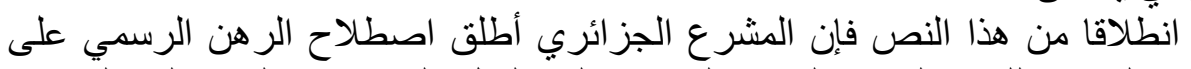

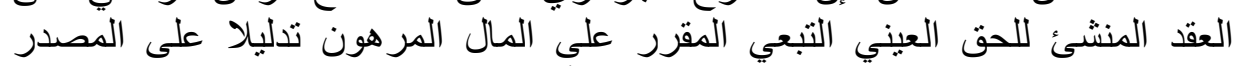

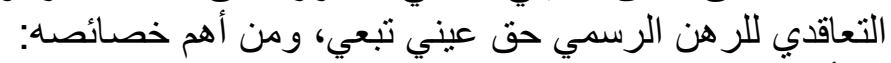

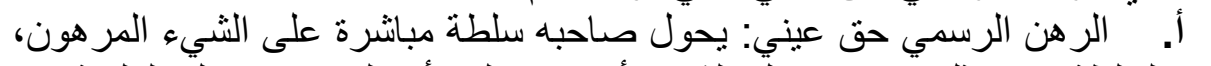

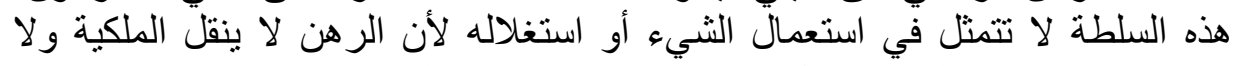

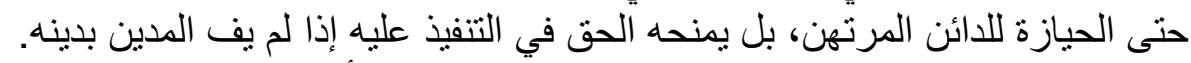

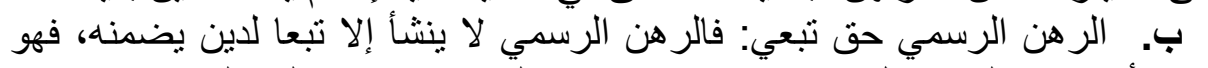

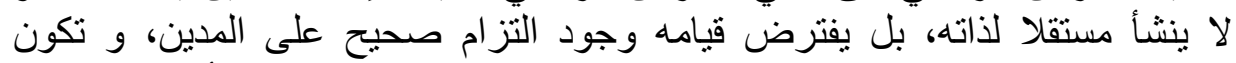

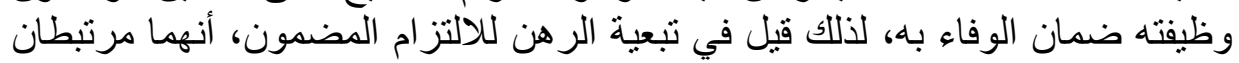
في صحتهما ووجود هما و القضائهما. لأنها.

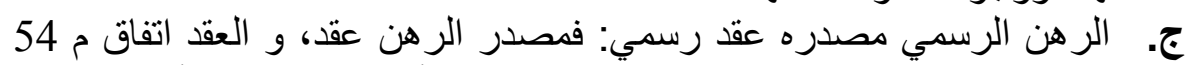

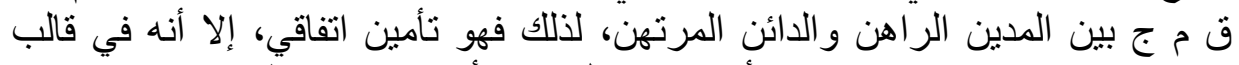

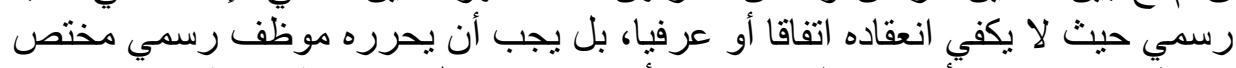

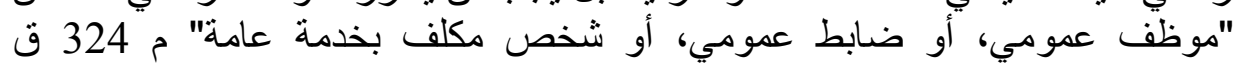

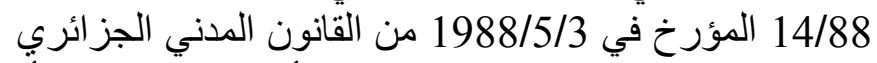

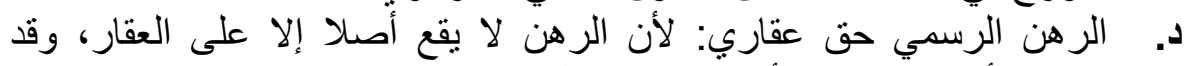

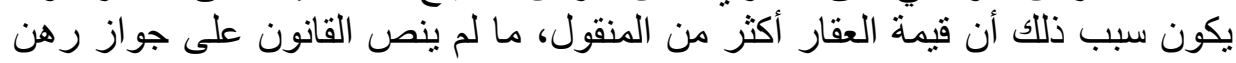

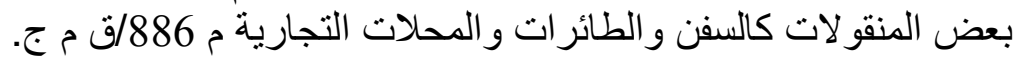

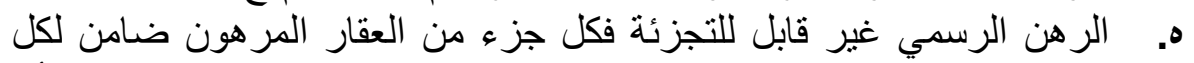

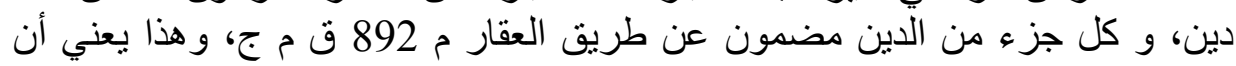

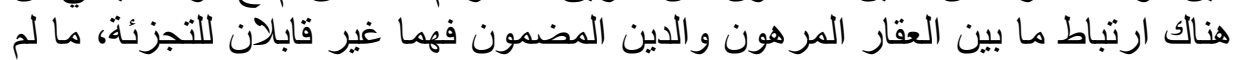

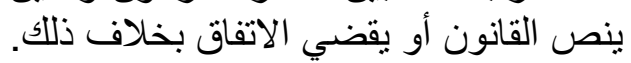

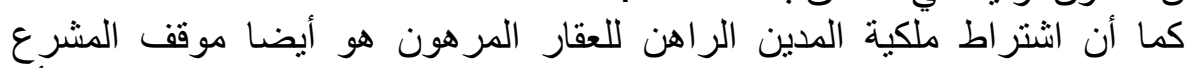

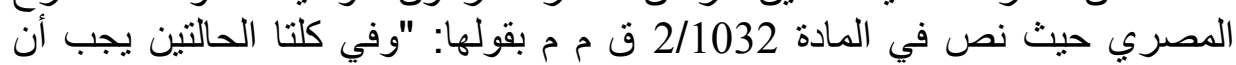

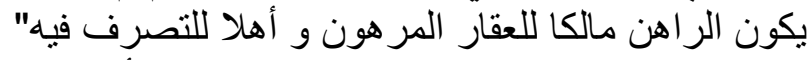

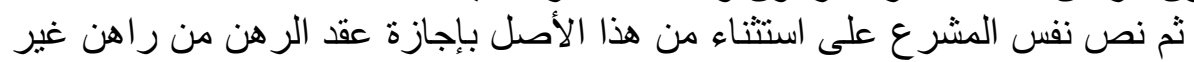

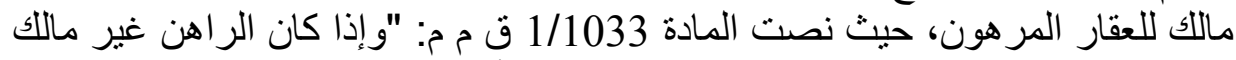

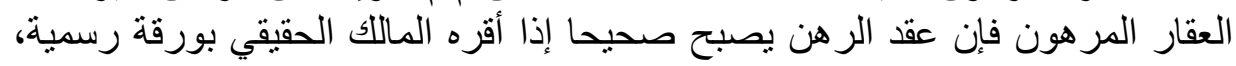

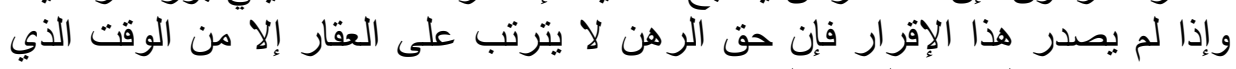
يصبح فيه هذا العقار مملوكا كالر اهن". 
ومع اشتراط الملكية لصحة عقد الرهن، فإن المشرع نظم عقد رهن على ملكية

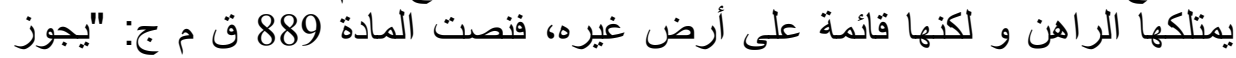

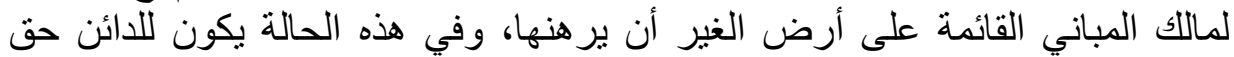

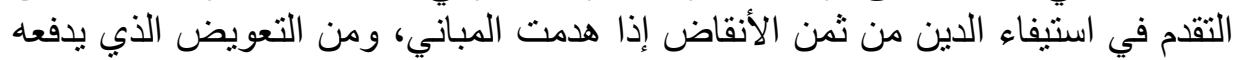

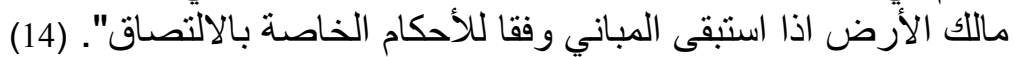

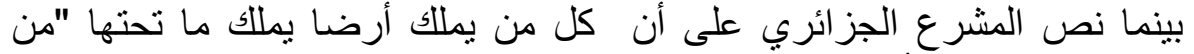

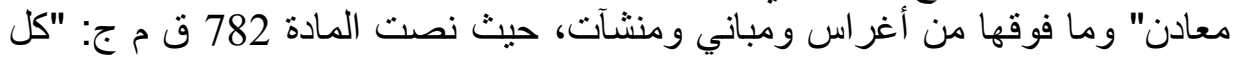

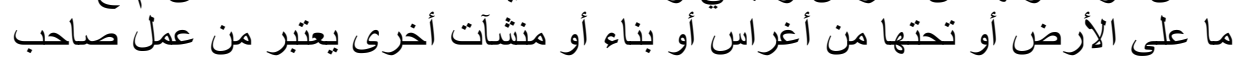

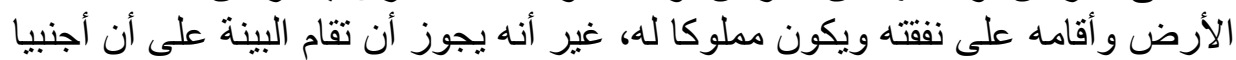

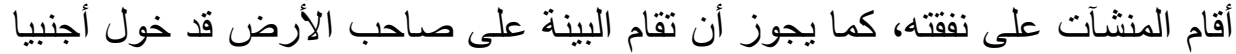

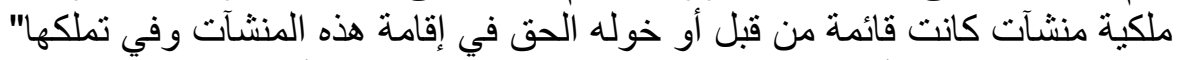

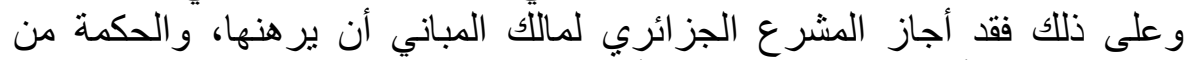

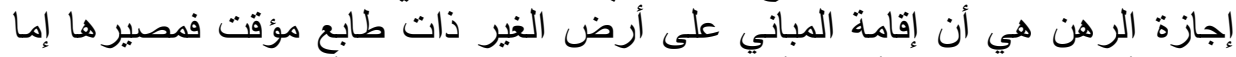

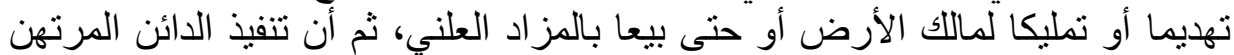

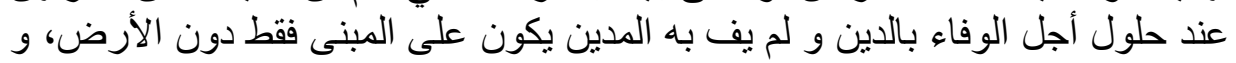

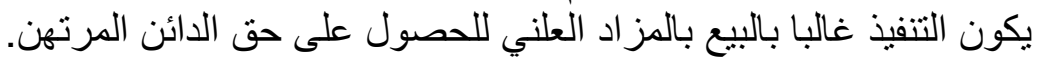

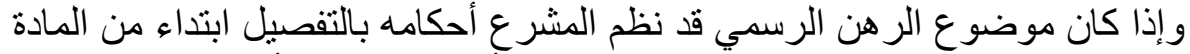

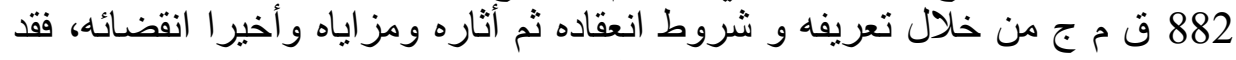

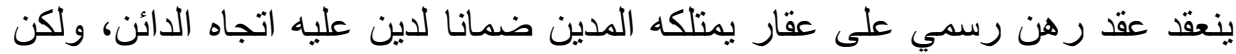

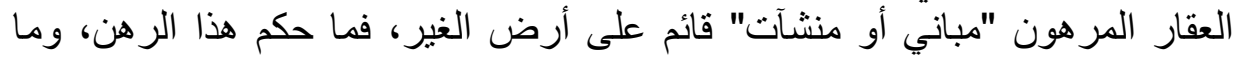

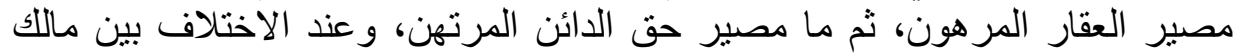

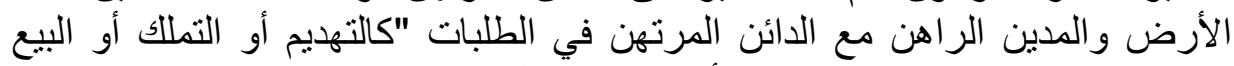
بالمز اد العلني" فمن يكون صـاحب الأولوية في قَّبول طلباته؟ المحور الثاني

رهن المباني القائمة على أرض الغير

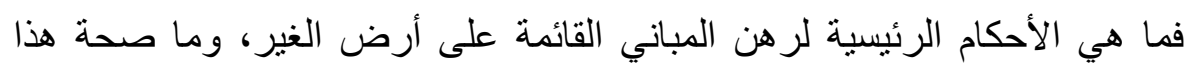

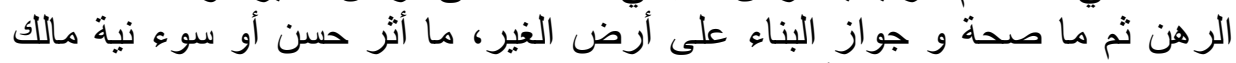

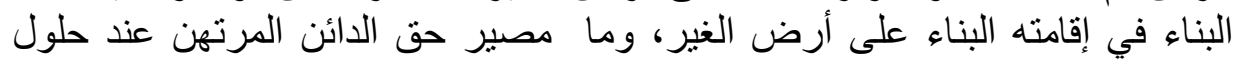

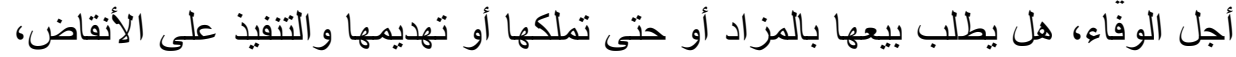

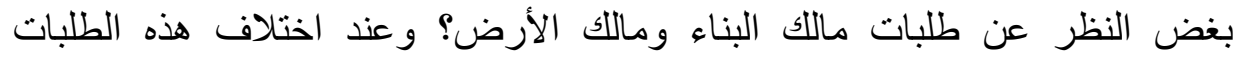

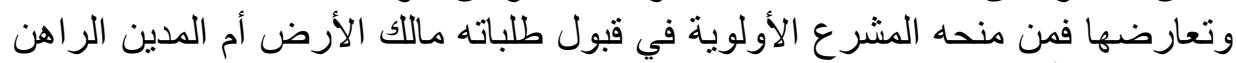

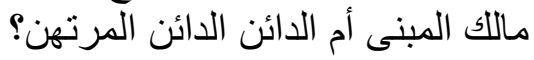

أولا: العلاقة بين مالك الأرض و ماللك المباني بالدائن المرتهن 


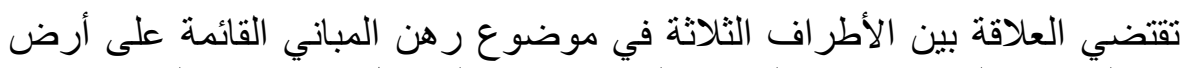

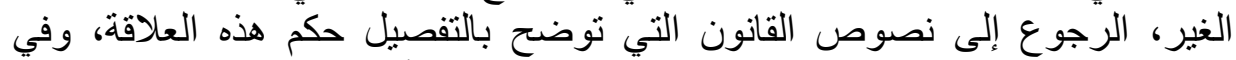

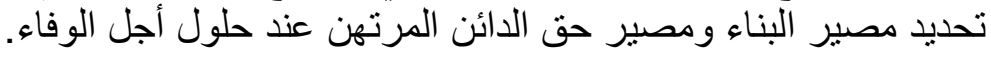

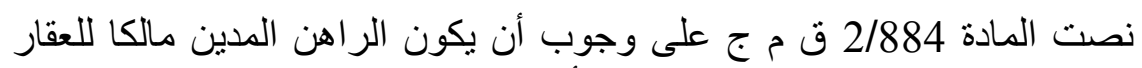

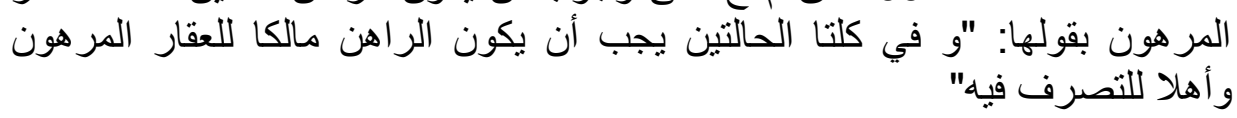

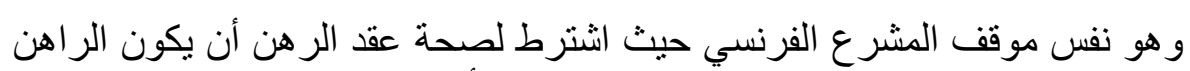

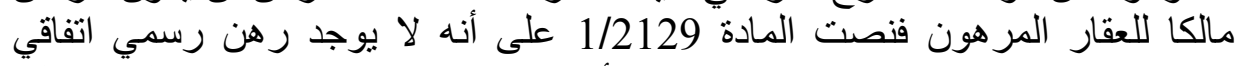

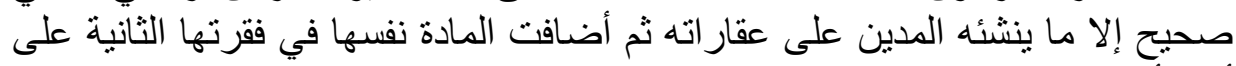

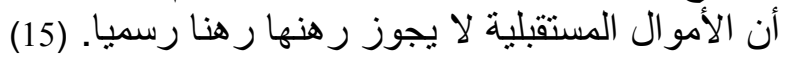

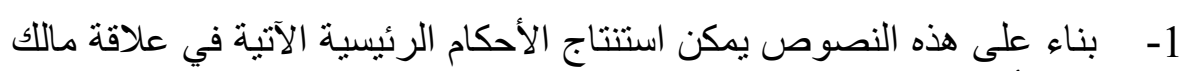
المبنى بمالك الأرض ومن ثم ثم بالدائن المرتهن.

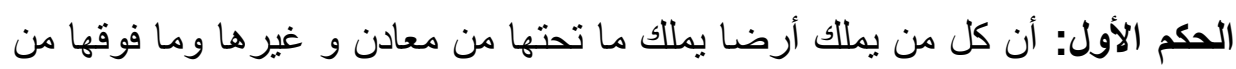

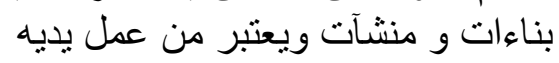

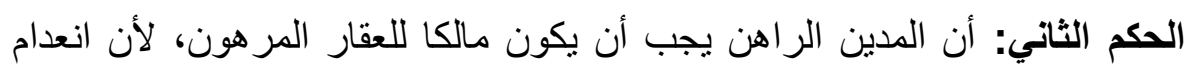

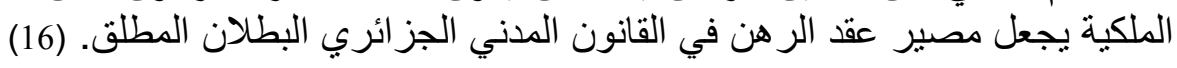

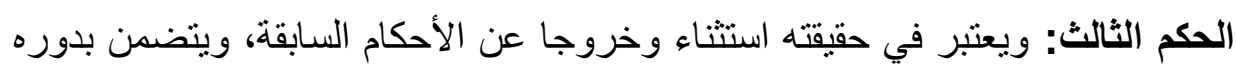
حكمين فر عيين:

الأول: يجوز لمالك المباني حتى و إن أقيمت على أرض غين غيره أن برهنه أنها،

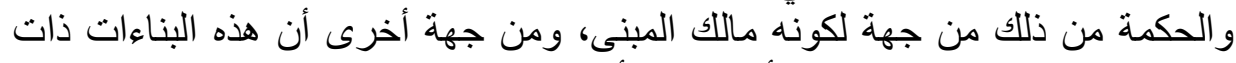

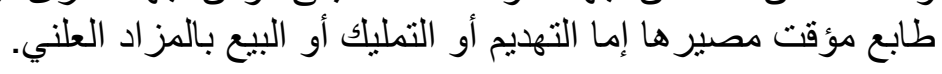

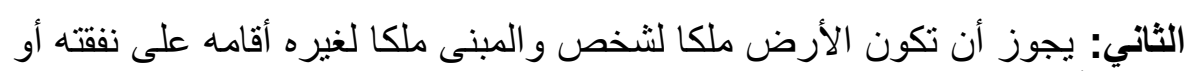
أن مالك الأرض ملكه المبنى.

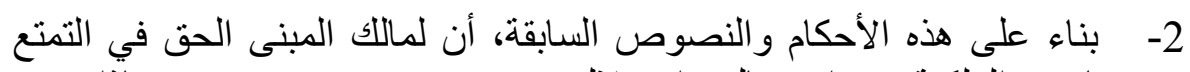

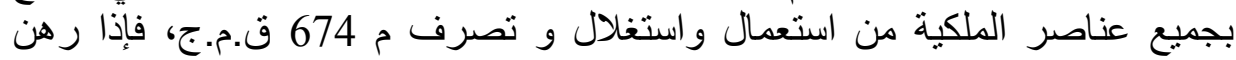

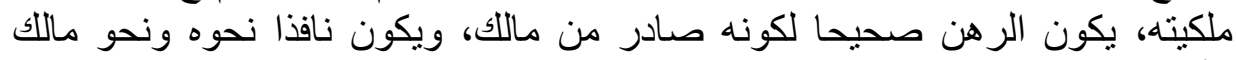
الأرض وحتى نحون الدائن المرتهن.

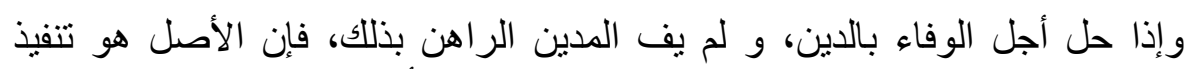

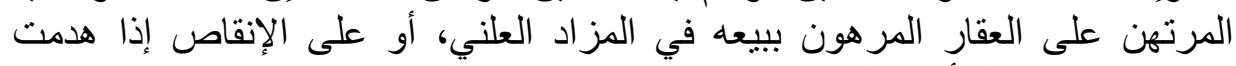

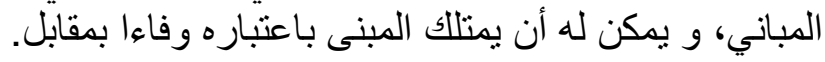


ولكن الإشكالات التي يثير ها موضوع رهن المباني القائمة على أرض الغير كثيرة

أهمها:

- إذا طلب مثلا مالك الأرض تهديما للمبنى القائم على أرضه، بينما طلب الدائن

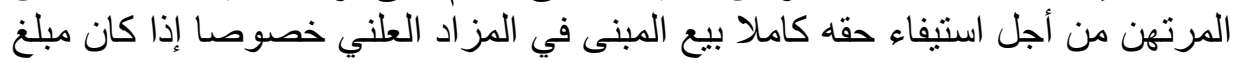

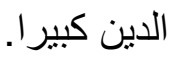

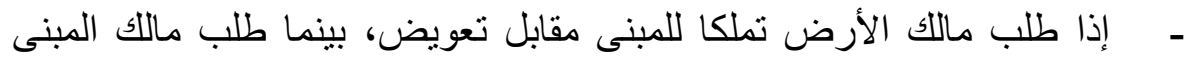

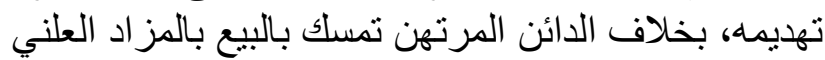

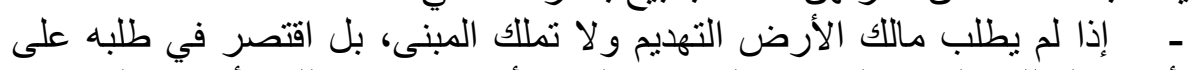

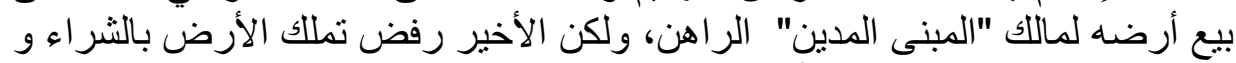

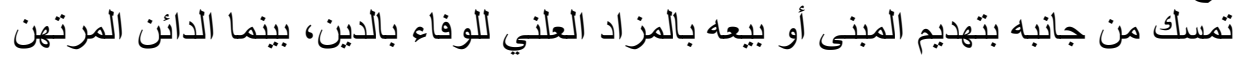
قبل تملك المبنى باعتباره وفاءا بمقابل كما قبل البيع بالئ بالمز الد العلني.

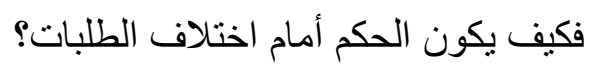

\section{ثثانيا/ الحلول التثريعية لمثكلة رهن المباني القائمة على أرض الغير الثاف}

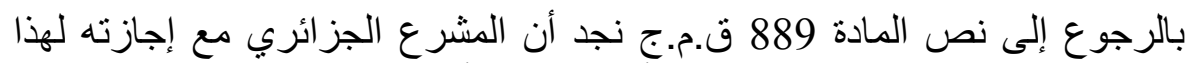

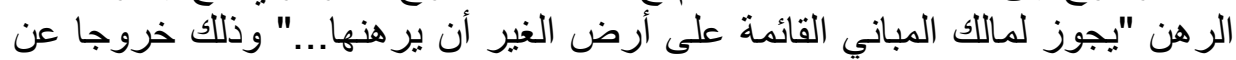

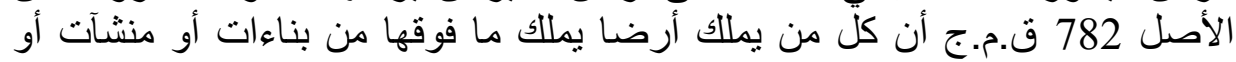

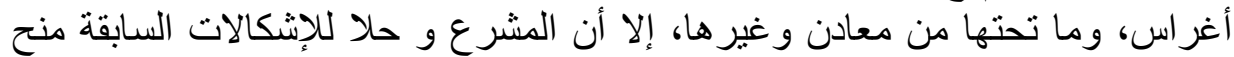

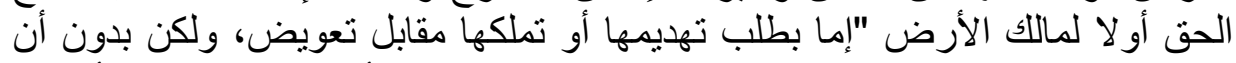

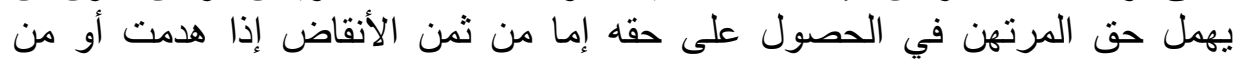
التعويض إذا تملكها الغير "مالك الأرض مثلات التهل

وتكون الحلول القانونية المقترحة عند تعدد طلبات الأطر اف و تباينها كما يلي:

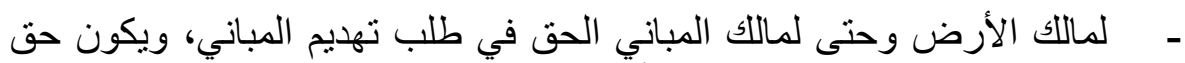

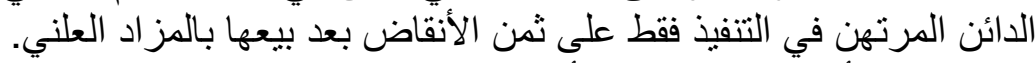

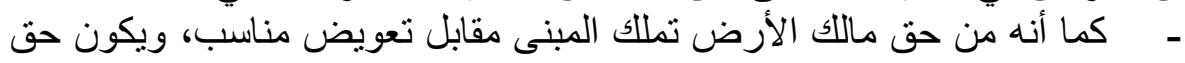

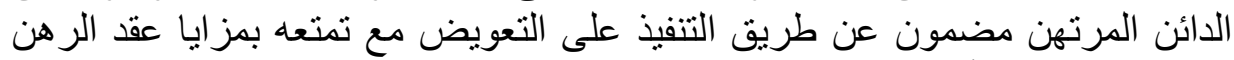

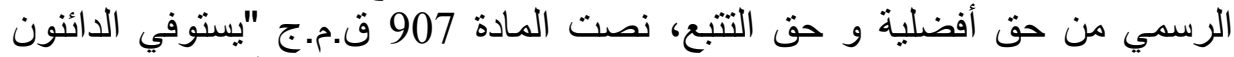

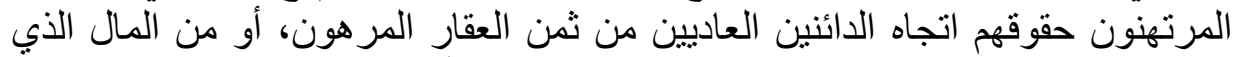

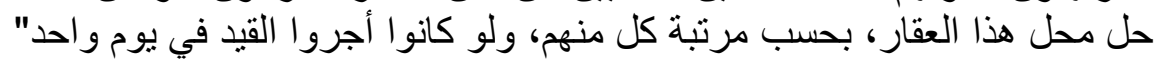

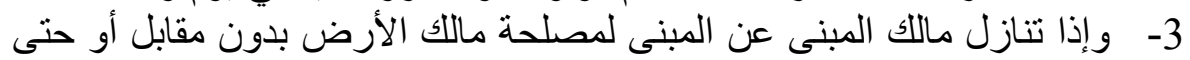

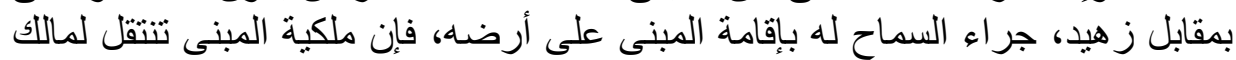

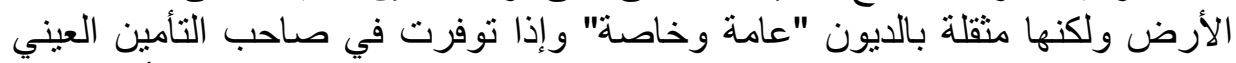

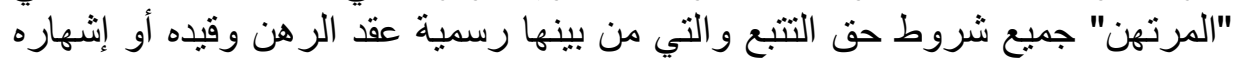
حتى يكون نافذا نحو الغير، فمن حق الدائن المرتهن إذا لم يف الدين الثين الراهن الهن بالدين 


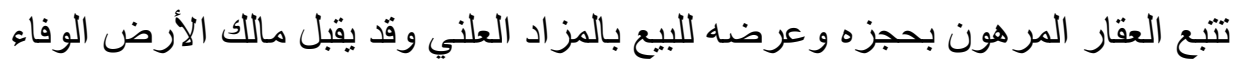

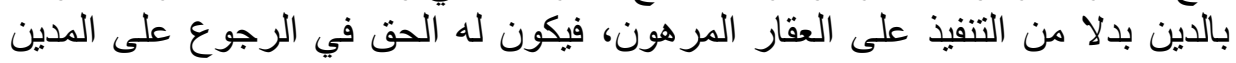

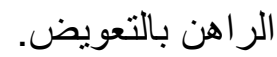

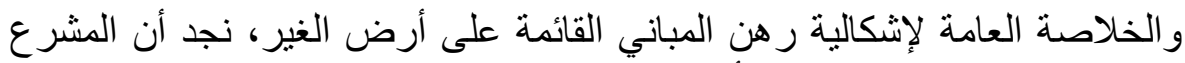

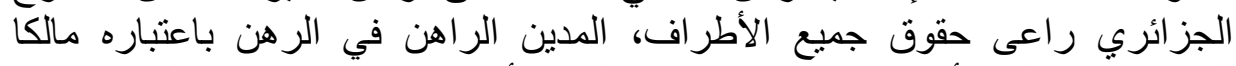

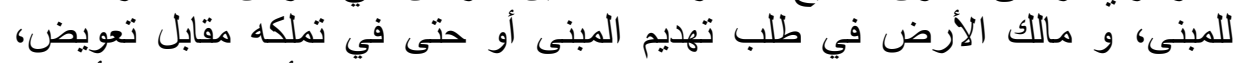

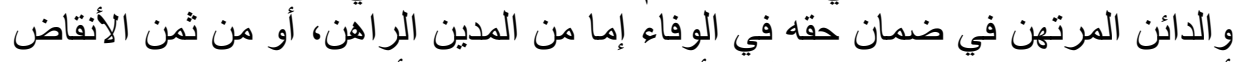

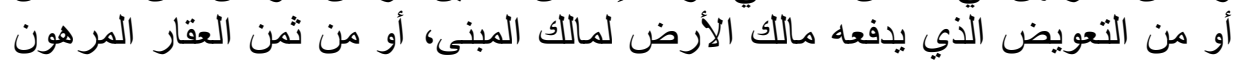
بعد بيعه في المز اد العلني.

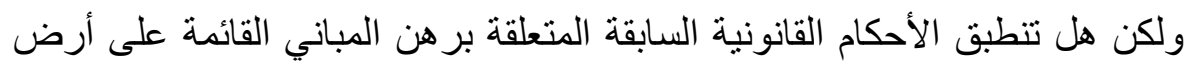

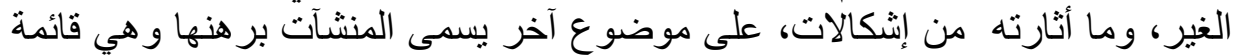

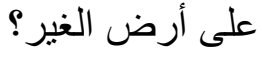




\section{المحور الثالث \\ رهن المنشآت القائمة على أرض الغير}

نظم المشرع الجزائري موضوع المنشآت les ouvrages القائمة على أرض الغير

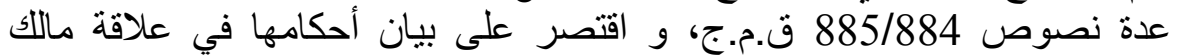
الأرض بمالك المنشآت في حالتي حسن و و سوء وع نية مالك المنشآت.

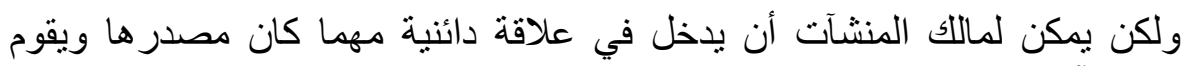
بر هن منشآتها للغير، فيعتبر حينئد مدينا راهنا في مواجهة دائن مرتهن فئن

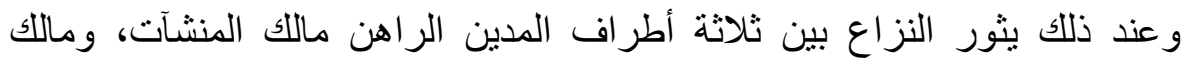

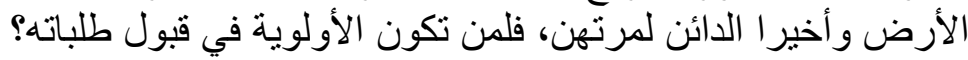
أولا: العلاقة بين و مالكك الأرض و ماللك المنشآت

تحكم العلاقة بين المالكين مالك الأرض بمالك المنشآت نص المادين مادين

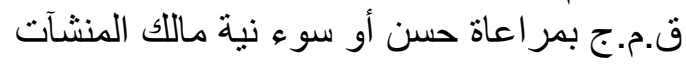

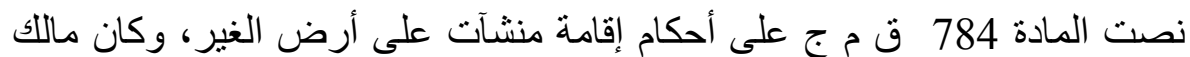

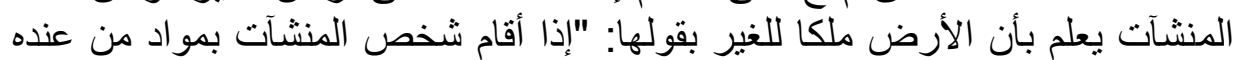

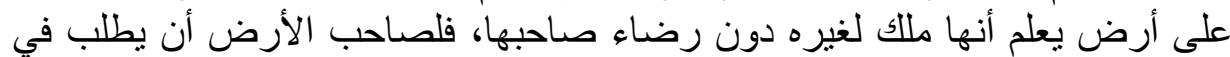

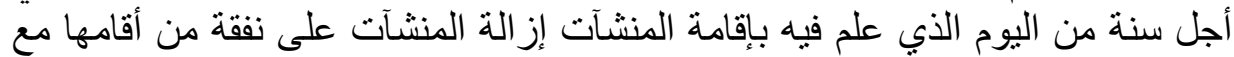

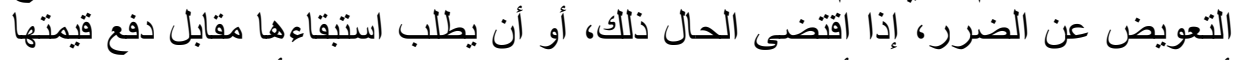

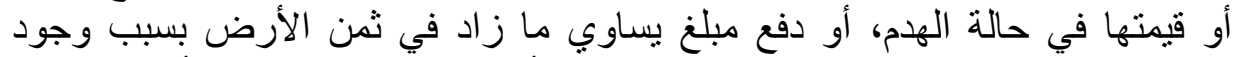

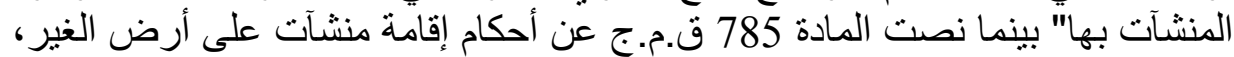

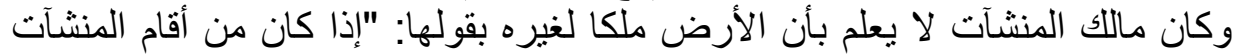

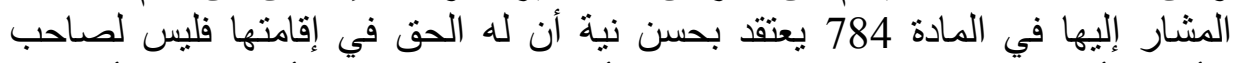

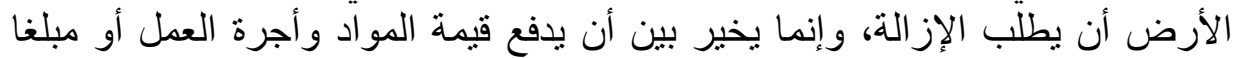

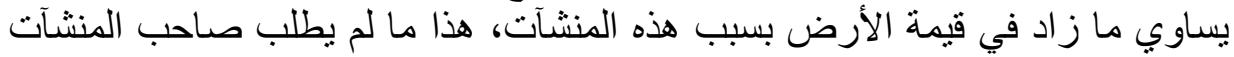

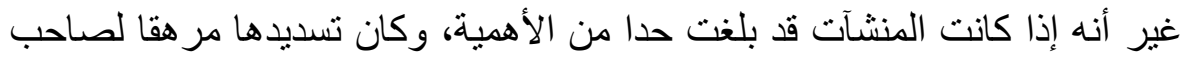

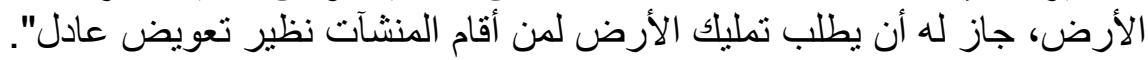
بناء على هذه النصوص القانونية و ما احتوته من أحكام قانونية في كل من حالتي التي

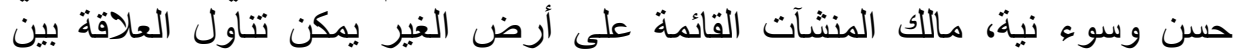

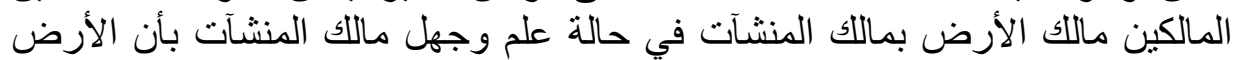

ملكا لغيره

1- حالة علم مالك المنشآت بأن الأرض ملكا للغير "سوء نيته" 


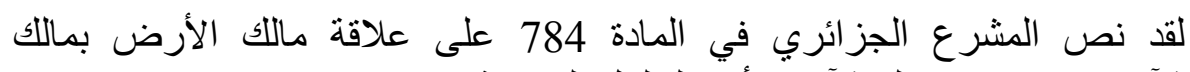

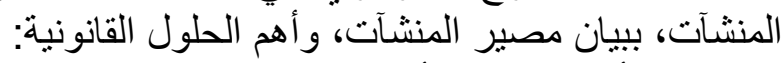

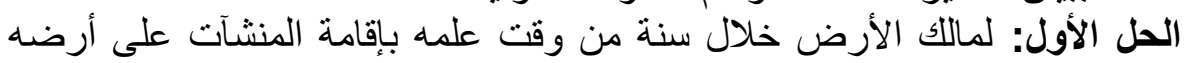

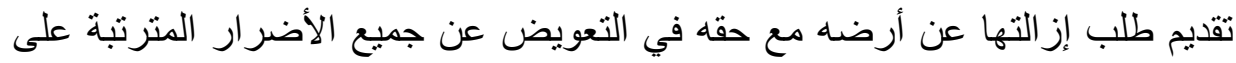

الحلّ الثاني: لمالك الأرض الحق في استيفاء المنشآت ملكا له، مقابل دفعه تعويضا التهديم.

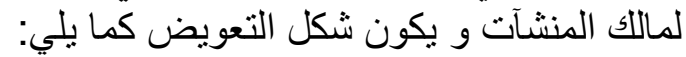
-

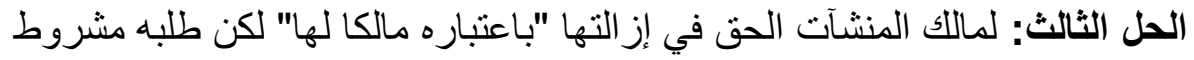

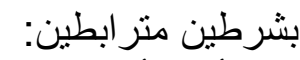

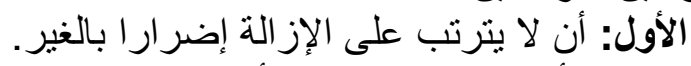

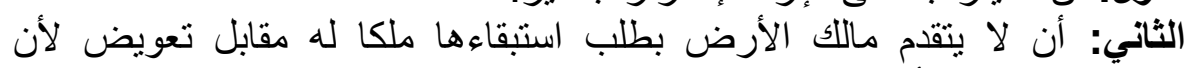

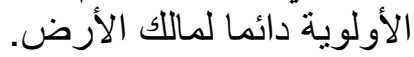

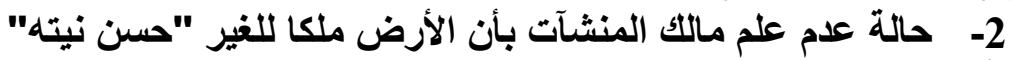

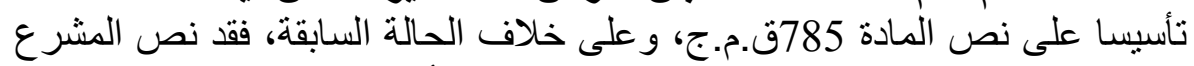

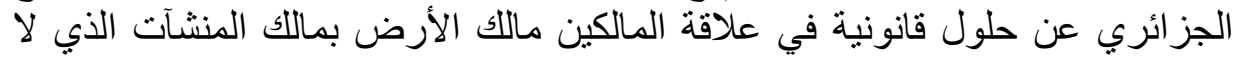

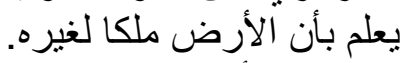

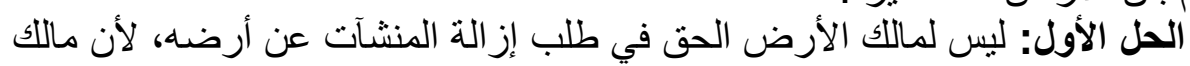

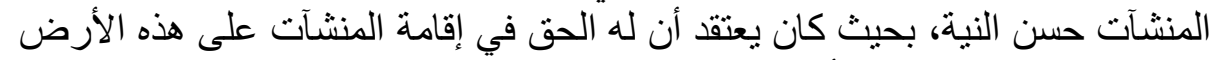

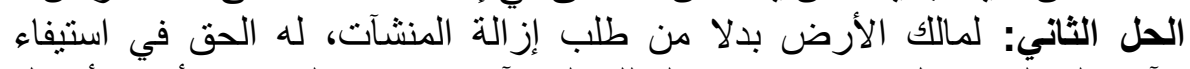
المنشآت ملكا لَّ، مقابل تعو يض يقدمه لمالك المنشآت، و و يتخذ التعويض له أحد الأشكال التالية:

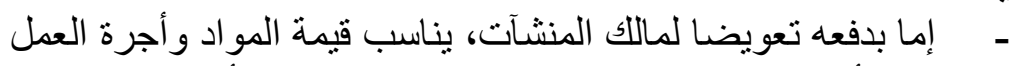

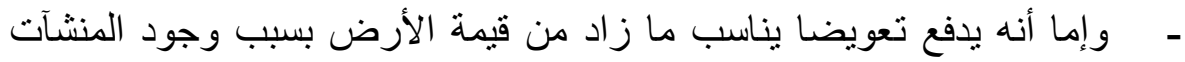

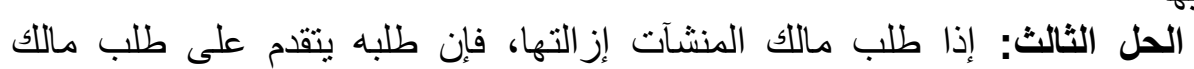

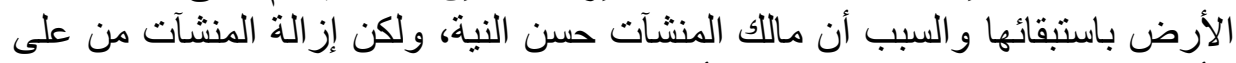

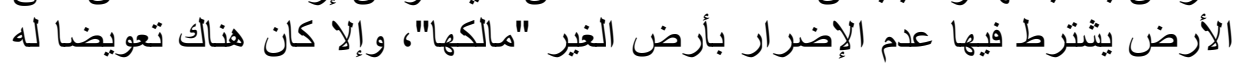

3- حق مالك الأرض تمليك أرضه لمالك المنشآت إذا كان ثمن المنشآت باهظا:

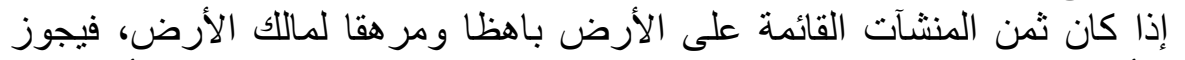

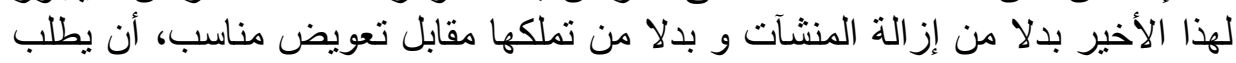

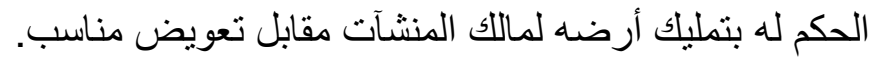


لكن المشكلة التي يثيرها الحل الرابع تتمثل في حالة رفض مالك المنشآت نملك

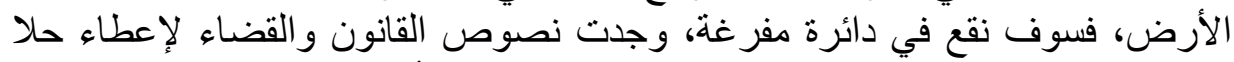

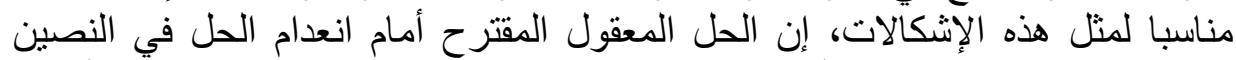

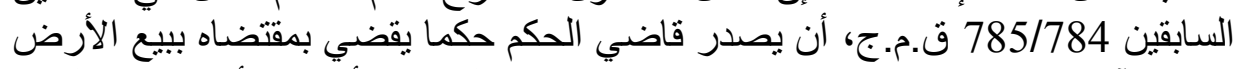
و المنشآت معا في المز اد العلني، وبذللك نحقق حماية لجميع الأطر اف أصحاب الصني الملكية، و الدائن المرتهن للمنشآت بحصوات الثهم على حقهم.

\section{ثانيا/ العلاقة بين مالك المنشآت و الدائن المرتهنين}

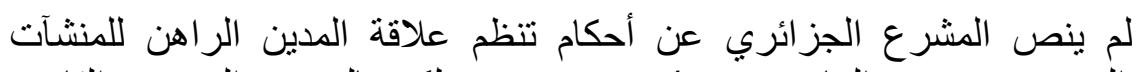

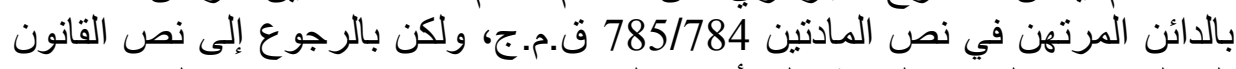

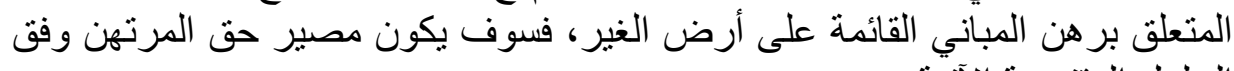

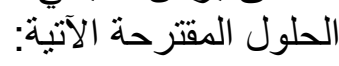

\section{الحل الأول: وفاء المدين الراهن بلهينه للائن المرتهن}

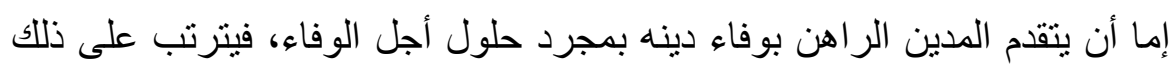

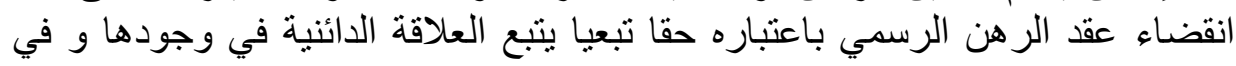
صحتها و في انقضائها.

$$
\text { الحل الثاني: تنفيذ الدائن المرتهن بحقه على الأنقاض }
$$

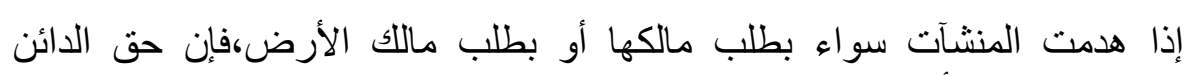

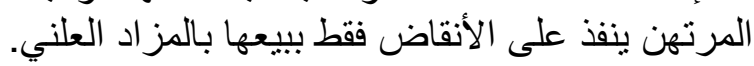

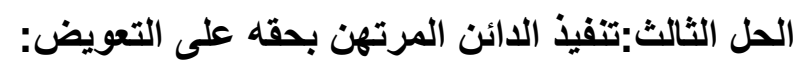

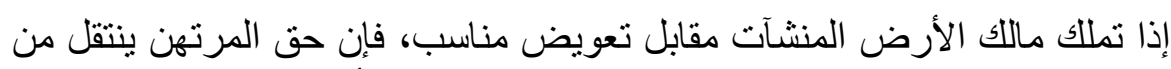

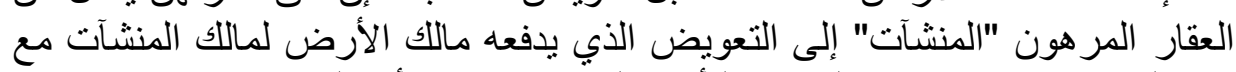

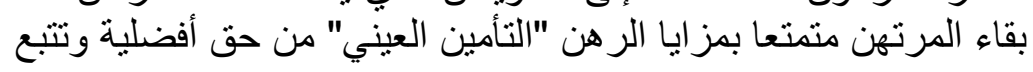
الحل الرابع: التنفيذ على المنشآت بيعها بالمزاد العلني أو بتملكها:

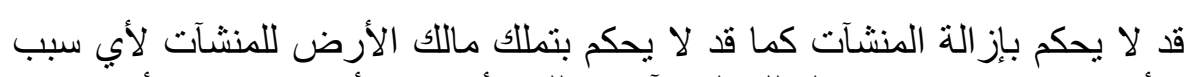

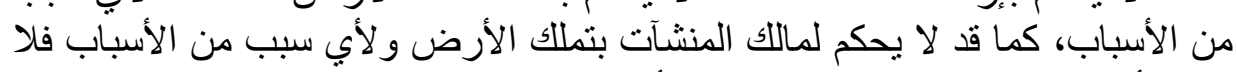

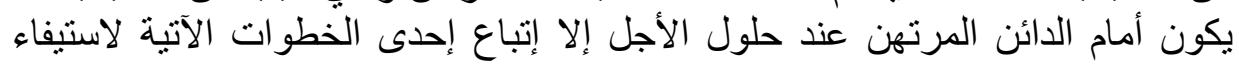
حقه:

- إما التنفيذ على المنشآت بييعها بالمز اد العلني و استيفاء حقه كاملا.

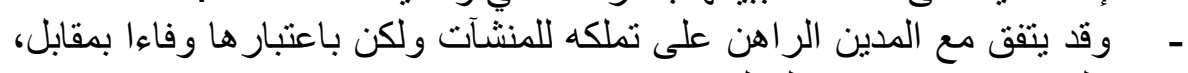
ولكن مع التعويض إن اقتضى الحال. 


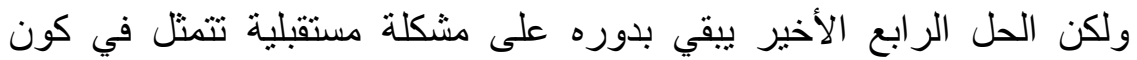

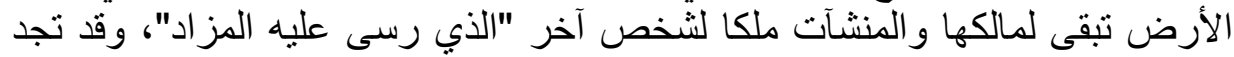

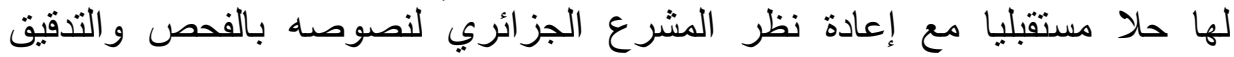
والتعديل وحتى الإلغاء.

الخاتمة

مع تنظيم المشرع الجزائري للملكية بالتفصيل باعتبار ها إحدى الحقوق العينية

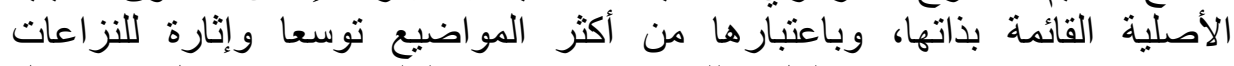

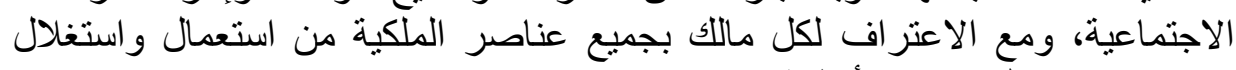
وتصرف وفق القو انين والأنظمة.

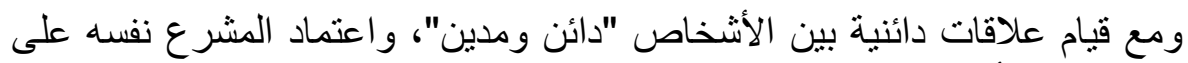

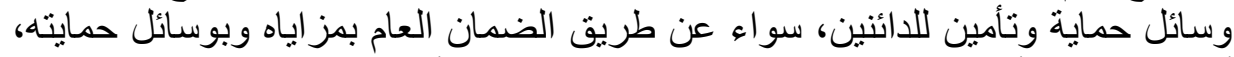

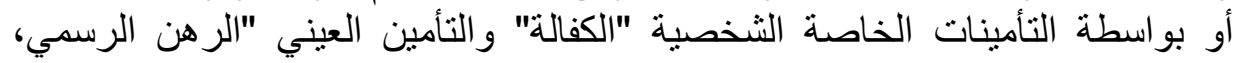

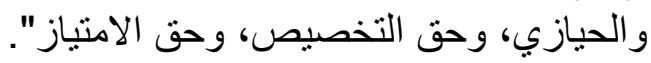

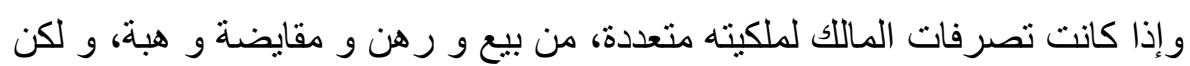

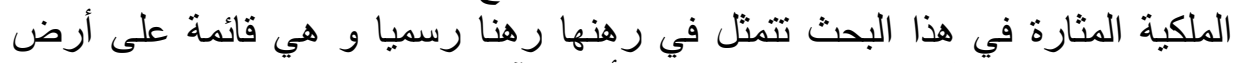
الغير، سو اء كانت الملكية في صورة مبأني أو منشآت.

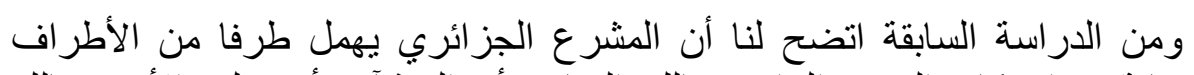

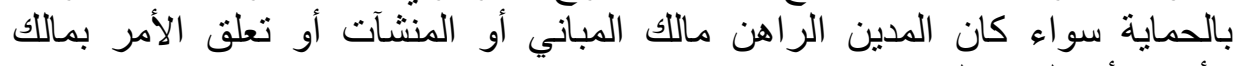

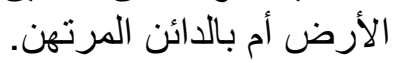

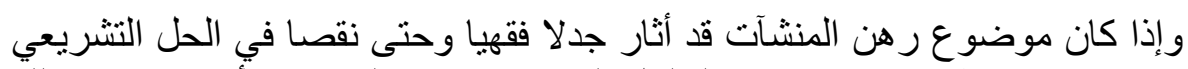

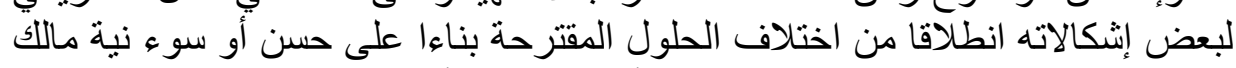

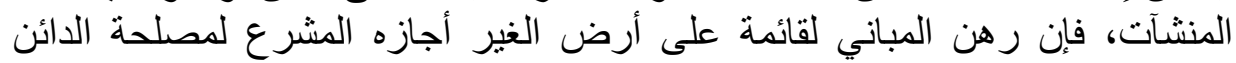

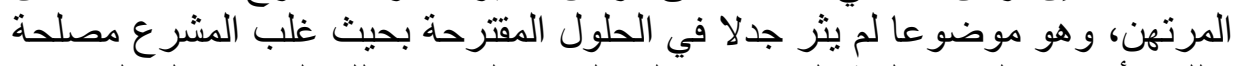

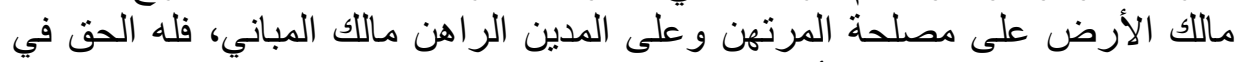

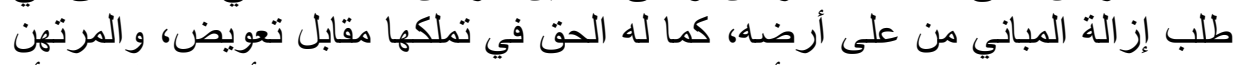

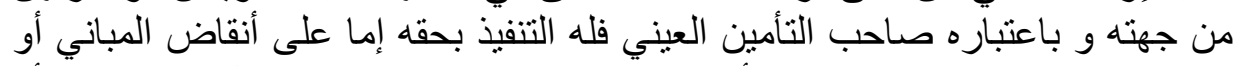

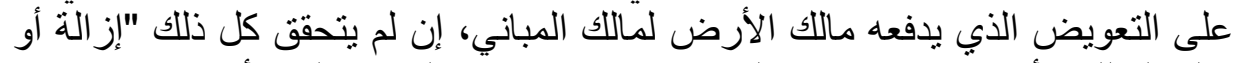

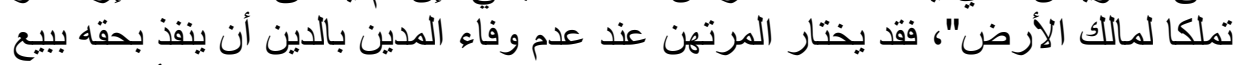

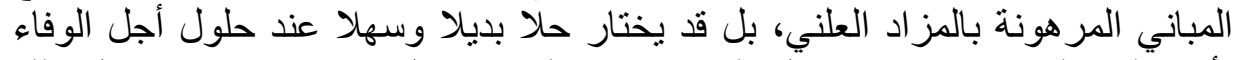

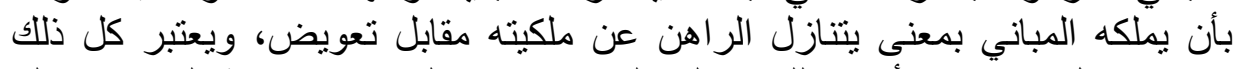
وفاءا بمقابل حتى وإن أمكن اللجوء إلى التعويض عن الفي الفارق بين قيمة المبنى و مبلغ الدين. 
1. Paul Ourliac \& Jehan de Malafosse, Histoire du droit privé ,01 , 3 trimestre, 1969 , p 331 , Presse Universitaire de France .

2. الدكتور : محمد صبري السعدي: الو اضح في شرح القانون المدني الجزائري 7.

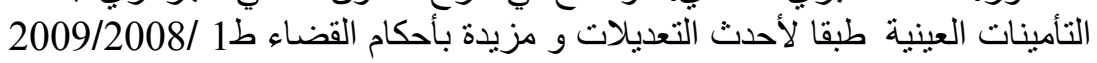
ص 7

3. Dupont Delestraint, Pierre, droit civil, 1988 - Mémentos Dalloz. 9e édition, p 139.

$$
\text { 4. الاكتور : محمد حسين منصور : النظرية العامة للائتمان ط } 2001 \text { ، ص } 5 \text { عن دار }
$$

5. Alex Weill,... et François Terré, droit civil, $2^{\mathrm{e}}$ ed, p 01, Dalloz , 1975.

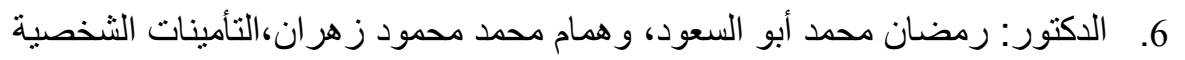
و العينية طبعة 1998، 1998، ص 12.عن دار المطبو عات الجامعية مصر.

7. Agostini Eric,Hubrecht George: droit civil, $13^{\mathrm{e}}$ ed 1983, p 178, Ed SIREY,Paris.

$$
\text { 10. }
$$

11. Code civil français, art $2114 / 1$ ( 1 ' hypothèque est un droit réel sur les immeubles affecté à l' acquittement d' une obligation....) ed $1974 / 1975$

12. القاضي: حسين عبد اللطيف حمدان: التأمينات العينية ، دراسة تحليلية مقارنة

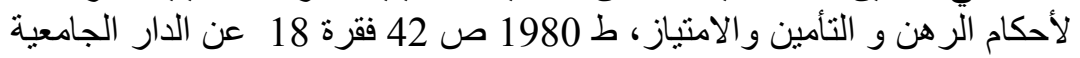

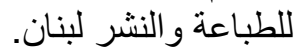

$$
\begin{aligned}
& \text { 13. وهو نفس النص والحكم الذي أخذ به المشرع المصري في نص المادة } 1038 \text { ق م } \\
& \text { 14. الدكتور: عبد الرزاق أحمد السنهوري: الوسيط في شرح القانون المدني ج 10 13، في }
\end{aligned}
$$

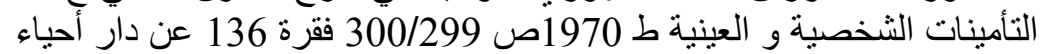

$$
\begin{aligned}
& \text { التر اث العربي لبنان. }
\end{aligned}
$$

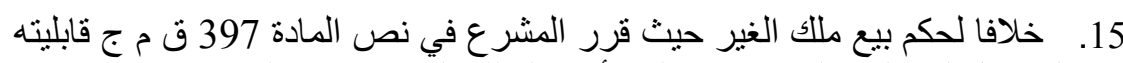

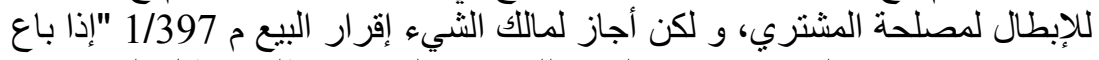

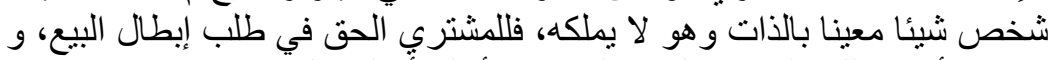

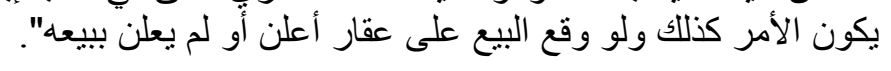


رهن المباني القائمة على أرض الغبر في القانون الدني الجزائري

16. م 1/398 ق م ج "إذا أقر المالك البيع سرى مفعوله عليه و صسار ناجز ا في حق

الكشتري". 